\title{
The Importance of Credit Program Scheme on Waste to Energy Program in Indonesia: Case Study on Tofu Industry
}

\author{
Noor Syaifudin ${ }^{1, *}$, Nurkholis $^{2}$, Rangga Handika ${ }^{3}$, and Roy Hendroko Setyobudi ${ }^{4,5}$ \\ ${ }^{1}$ Fiscal Policy Agency, Ministry of Finance of Republic of Indonesia,Notohamiprodjo Building, ${ }^{\text {st }}$ \\ Floor, Jl. Wahidin No 1, Senen, Jakarta, 10710, Indonesia \\ ${ }^{2}$ Faculty of Economics, University of Indonesia, Economics Department Building, 1st Floor, Depok, \\ West Java, 16424, Indonesia \\ ${ }^{3}$ College of Business Administration, Abu Dhabi University, Abu Dhabi Campus, P.O Box 59911, \\ Abu Dhabi, Uni Arab Emirates \\ ${ }^{4}$ Waste Laboratory University Muhamadiyah of Malang, Jl. Raya Tlogomas No. 246 Malang, 65114, \\ Indonesia \\ ${ }^{5}$ Indonesian Association of Bioenergy Scientist and Technologist. BPPT Building II, Jakarta, 10340, \\ Indonesia
}

\begin{abstract}
This study aimed to provide a basis for future policy making in supporting the waste to energy from tofu in Indonesia. The policy studied was the credit program scheme for tofu industry. The financial feasibility, as well as cost and benefit analysis, were conducted to meet the objectives. Tofu industries are mostly small-sized industry which supports people with middle-to-low incomes. On the other hand, tofu industry also contributes significant amounts of emissions. Thus this calls for government intervention to encourage tofu industries to convert their wastes to energy. The result of the study shows that the developments of biogas reactors are feasible for size $84 \mathrm{~m}^{3}$ and $94 \mathrm{~m}^{3}$. The study also found that for both sizes, the benefits are higher than the costs.
\end{abstract}

Key words: Tofu industry, waste to energy, credit program, feasibility study

\section{Introduction}

The steadily increasing price of energy has resulted in higher energy costs to industry for production and simultaneously a larger portion of household expenditures on energy. The growing energy demand and prices also affect the State Budget contributing to ever higher energy subsidies. Further, the high dependency on fossil fuel energy contributes to slowing down efforts to reduce greenhouse gas (GHG) emissions. Thus, biomass utilization by conversion from Waste to Energy (WtE) is an alternative energy source that allows reductions in GHG emissions.

*Corresponding author: soib2007@gmail.com 
Utilization of agricultural and other wastes as an energy alternative provides advantages. Firstly, there is scope for overall improvement in energy efficiency because agricultural/other wastes contain large energy potential and are wasteful if not utilized. Secondly, the use of agricultural/other wastes can be very cost efficient because waste disposal is sometimes more costly than using the waste itself. Thirdly, utilization of wastes reduces needs for landfilling/piling which can generate significant costs in waste management.

A number of existing credit promotion programs have been supported by the Ministry of Finance (MoF) including the e Credit for Food and Energy Security which to date in the energy area has mainly targeted on biofuel raw materials [1-3]. Such interest subsidy programs may provide useful model for the development of WtE credit support programs but are likely to require adaptation.

Financing WtE investment through credit programs, besides of having potential benefits, has a logical consequence on the cost side. By providing the supports to the financing in the $\mathrm{WtE}$, it is expected that the benefits are expected to be greater than the costs incurred. Thus, this study purposed (i) to elaborate the industry and the possibility of the financing, (ii) to provide a basis for future policy making, and (iii) provide the necessary analysis of the costs and benefits of a WtE investment financing through a credit program.

\section{Objectives}

This study aims to identify and to analyze the costs and benefits associated with the proposed scheme of investment financing credit program to support the development of WtE for tofu industry. The study was also supported with the financial feasibility analysis to measure the viability of the program from the financial perspective. It is expected that the results of these analysis can be used for setting policies related to $\mathrm{WtE}$ investment financing through credit program.

\section{Methodology}

The study was conducted mainly based on the financial analysis (FA), cost and benefit analysis (CBA) and literature review. The assumptions in the FA and CBA of development projects in the WtE were based on a primary survey and secondary data from the Ministry of Energy and Mineral Resources (MEMR) and the MoF. The secondary data was captured from various programs of $\mathrm{WtE}$ investment that has been undertaken by the MoF and the MEMR.

\subsection{Financial feasibility analysis}

To find the proper indicators for the study, there are several criteria to be fulfilled. The criteria were including net present value (NPV) and internal rate of return (IRR). NPV is the different between the present value from the positive cash flows and negative cash flows. On the other hand, the IRR describes the rate of return on net investment. In the project evaluation, the project is feasible when the NPV level is equal to or greater than the IRR and bigger than the discount rate.

Other financial indicators are Profitability Index (PI) and Return on Investment (ROI). $\mathrm{PI}$ is the comparison between net cash flow in the future with present cash flow. ROI is the ratio of net income to expenses. Investment is feasible to run when PI is greater than 1 . A positive ROI shows that the investment is feasible to run. 
Moreover, FA is already known and commonly used in several studies. The application of FA can be used either as a single method or combined with the other method such as technical analysis [4] as well as regional and sectoral economic approach [5]. FA was also employed in measuring the feasibility of the introduction of new energy sources including waste cooking oil [6], solar energy [4] and also for the feasibility of mass production [7].

\subsection{Cost and benefit analysis}

The Cost and Benefit Analysis is the process to identify, calculate, and compare the costs and the social benefits that are produced by project/investment activities. The justification for cost and benefit analysis is the limited utility of narrow financial analysis that cannot capture all the benefits and losses that have an impact on the society as a consequence of investment project. Indicators that focus only on financial analysis can be wrong if used as an indicator of social welfare because some projects/investments result in goods that cannot be sold freely in the market, such as garbage management, emission reductions, or health facility repairs.

One method of cost and benefit analysis that is commonly used are benefit-cost ratios (BCR). Benefit-cost ratios (BCR) basically are the comparison between the present values of benefit values that are being received by society to the cost that society must pay as a result of the project. Projects are judged as feasible to run if the BCR is larger than 1 . Therefore the value of benefits over time are larger than estimated cost values.

Where

$$
B C R=\frac{\sum_{i=1}^{n} \frac{B n}{(1+i)^{n}}}{\sum_{i=1}^{n} \frac{C n}{(1+i)^{n}}}
$$

$\mathrm{BCR}=$ Benefit and cost ratio

$\mathrm{Bn}=$ benefit at the end of period

$\mathrm{Cn}=$ cost at the end of period

$\mathrm{n}=$ period of investment

There is a wide range use of BCR in measuring the feasibility of the project or program including health [8-10], natural resources management [11, 12], and renewable energy from wind power [13]. Thus, it is expected that the combination of the application FA and CBA in this study may provide comprehensive analysis and may also provide broad policy recommendation.

\section{Development of biogas reactors from tofu industry waste}

The tofu industry plays an important role in Indonesia. The industry is a small-sized industry which supports people with middle-to-low incomes. In Indonesia, there are 177 tofu and tempeh cooperatives in 18 provinces. There are 115000 units of tofu makers with $1 \times 10^{6}$ workers being absorbed by the industry. The tofu industry depends a lot on the availability of soybean. Approximately, the tofu industry needs $132 \mathrm{t}$ of soybeans per month.

The tofu industry contributes significant amounts of emissions. There are 84000 business entities in Indonesian tofu industry. With production capacity exceeding 2560000 $\mathrm{t}$ per year, the tofu industry produces $20 \times 10^{6} \mathrm{~m}^{3}$ of liquid emissions per year, which is equivalent to $1 \times 10^{6}$ t of carbon dioxide. With $80 \%$ of the tofu industry concentrated on 
Java Island, the liquid emissions from the tofu industry on Java Island may be around $800 \times$ $10^{9} \mathrm{t}$ of carbon dioxide.

The tofu industry waste contains a high concentration of organic materials in general, such as protein, carbohydrate, fat, and oil. That high concentration of organic materials potentially emits methane. Similar to cattle farm waste, tofu industry waste can also be processed with a biogas reactor.

One type of tofu industry waste processing technology is the use of a Fix Bed Reactor which is constructed with an anaerobic system. This system needs large tracts of land and does not need energy for aeration. The advantage of this system is its good output. This system will result in a form of biogas and dregs and also water for feeding fish. Besides that, the process is more stable and creates less mud. Tofu liquid waste processing units consist of the main unit of the digester, sewage collection pipe network, gas container, trickling, filter, processed residual waste network, and processed residual water pool.

\section{Existing credit programs}

Among fiscal facilities that are provided by the government, there are some that are relevant to the credit programs, among others:

\subsection{Interest subsidy pattern}

This scheme will allow the government to provide fiscal facilities to the beneficiaries by providing a fund from the budget to pay the interest as the result of the implementation of the program. There several interest subsidy pattern and among others are: first, Credit for Food and Energy Security (Kredit Ketahanan Pangan dan Energi/KKP-E) [1] that supports the food security program and the biofuels raw materials development program and emphasizes the role of funding through the involvement of national banks with interest subsidies from the government. In addition, to ensure supply, distribution and funding accountability of the KKP-E the scheme needed to be created with an integrated credit mechanism.

Second, Credit for Bio Energy Development and Plantation Revitalization [14]. In order to accelerate the development smallholdings plantation, the Minister of Agriculture has issued Regulation of the Ministry of Agriculture [15] about Estate Development through a Plantation Revitalization Program. This program was purposed to enhance the development of estate crop plantations through expansion, regeneration and rehabilitation. This is related to the implementation of development programs for feedstock crops especially biofuels and plantation revitalization funding support which involves the national banks. Third, Credit for Businesses Program [16]. This scheme is purposed to accelerate the development of economic activities in the real sector to alleviate poverty and expand work opportunities. Four, Credit for Cattle Breeding (KUPS) [17, 18]. Under this scheme, the government committed to develop one million cows over five years period. To smooth the program, the business community were provided with adequate rate in terms of subsidized interest loans executed via an executing bank.

\subsection{Assurance services pattern}

The empowerment of Micro, Small, Medium Enterprises and Cooperatives (MSME) to support job creation, and poverty reduction was pursued through the issuance of a government policy package in 2007. To improve MSME access to financing sources, it was 
considered necessary to provide credit/bank financing with soft and affordable requirements backed by a guarantee facility from the Government.

\subsection{Combination pattern program (Indonesia regional water companies)}

In order to speed up the drinking water supply, the Central Government with regard to the financial capacity of the State has guaranteed the repayment of bank loans and subsidies on the interest charged by banks [19]. The guarantee is for the debt of regional (local) water (supply) companies while providing interest subsidies on loans by the banks to local water companies. This step is expected to improve the company's financial condition and ultimately facilitate the supply of clean water in the area. Credit support is given only for investment, based on the agreement between the regional water companies and the bank.

\section{Credit for Food and Energy Security (KKP-E)}

Below is a further description of KKP-E as the potential incentive for the WtE from tofu program.

Table 1. Description of KKP-E.

\begin{tabular}{|c|c|c|c|c|c|c|}
\hline $\begin{array}{c}\text { Definitio } \\
n\end{array}$ & $\begin{array}{c}\text { Financing } \\
\text { Object }\end{array}$ & $\begin{array}{c}\text { Financing } \\
\text { Subject }\end{array}$ & Credit Size & $\begin{array}{l}\text { Interest } \\
\text { Rate }\end{array}$ & $\begin{array}{c}\text { Participant } \\
\text { Interest } \\
\text { Expense }\end{array}$ & $\begin{array}{l}\text { Interest } \\
\text { Subsidy }\end{array}$ \\
\hline $\begin{array}{l}\text { Credit in } \\
\text { order to } \\
\text { improve } \\
\text { food } \\
\text { security } \\
\text { and } \\
\text { energy }\end{array}$ & $\begin{array}{l}\text { Business } \\
\text { activities that } \\
\text { can be } \\
\text { funded: } \\
\text { development } \\
\text { of food } \\
\text { crops, } \\
\text { horticultural } \\
\text { crops } \\
\text { development, } \\
\text { plantation } \\
\text { development, } \\
\text { procurement } \\
\text { of food (rice, } \\
\text { corn, } \\
\text { soybean and } \\
\text { fisheries), } \\
\text { livestock, } \\
\text { arrests and } \\
\text { fish farming, } \\
\text { procurement/ } \\
\text { rejuvenation } \\
\text { equipment, } \\
\text { machinery } \\
\text { and other } \\
\text { means to } \\
\text { support other } \\
\text { business } \\
\text { activities. }\end{array}$ & $\begin{array}{l}\text { Farmers/ } \\
\text { ranchers/ } \\
\text { growers/ } \\
\text { fishermen } \\
\text { and fish } \\
\text { farmers who } \\
\text { are members } \\
\text { of groups } \\
\text { and/or } \\
\text { cooperatives }\end{array}$ & $\begin{array}{l}\text { - Maximum } \\
\text { IDR } 100 \\
\text { million per } \\
\text { person } \\
\text { • Maximum } \\
\text { IDR 500 } \\
\text { million per } \\
\text { farmer } \\
\text { groups and } \\
\text { cooperatives }\end{array}$ & $\begin{array}{l}\text { - KKP-E } \\
\text { Plantation: } \\
\text { LPS + } 5 \% \\
\text { - KKP-E } \\
\text { Non- } \\
\text { Plantation: } \\
\text { LPS + } 6 \%\end{array}$ & $\begin{array}{l}\cdot \text { KKP-E } \\
\text { Plantation: } \\
7 \% \\
\cdot \text { KKP-E } \\
\text { Non- } \\
\text { Plantation: } \\
6 \%\end{array}$ & $\begin{array}{l}\cdot \text { KKP-E } \\
\text { Plantation: } \\
5 \% \\
\cdot \text { KKP-E } \\
\text { Non- } \\
\text { Plantation: } \\
7 \%\end{array}$ \\
\hline
\end{tabular}


KKP-E is purposed to improve food and energy security. The coverage is quite wide from the development of crops to the rejuvenation of equipment. This means that in the $\mathrm{WtE}$ from tofu program, it may be used to improve the quality of the tofu as well as increasing the machinery capacity of the conversion. The subject also covers the low-level farmers either as an individual or as a group. With the low-interest rate caused by the interest subsidy, it is expected that farmers will be interested in joining the program.

\section{Result and analysis}

Prior to further analysis with the feasibility of the financial support mechanism, the general assumptions were set. This was purposed to provide the basic scheme for the government to support with the financial intervention from the budget. It was also aimed to set the minimum requirement for the scheme to be financially feasible. The general assumptions were then provided in Table 2 as follows.

Table 2. General assumptions.

\begin{tabular}{|l|l|l|}
\hline No & \multicolumn{1}{|c|}{ Item } & \multicolumn{1}{c|}{ Amount } \\
\hline 1. & Loan term & $5 \mathrm{yr}$ \\
\hline 2. & Economical period & $20 \mathrm{yr}$ \\
\hline 3. & LPS interest rate/ Lending rate & $7.5 \% / 6 \%=$ total $13.5 \%$ \\
\hline 4. & Exchange rate 1 USD & IDR 11500 \\
\hline 5. & SME income tax rate & $1 \%$ of the turnover \\
\hline 6. & Big industry income tax rate & $35 \%$ of taxable profits \\
\hline 7. & Substituted Gas & Subsidized LPG \\
\hline 8. & Diesel & Non-Subsidized Diesel \\
\hline 9. & No Carbon Trade & 0 \\
\hline 10. & Financial Feasibility & $\begin{array}{l}\text { NPV }>0, \text { IRR }>\text { market interest rate } \\
(12 \%), \text { ROI }>0, \text { Profitability Index }>1\end{array}$ \\
\hline 11. & Various size of biogas reactors & $\begin{array}{l}\text { MEMR }=90 \quad \mathrm{~m}^{3} \quad \text { (without cleaner } \\
\text { production development) } \\
\text { MoE }=94 \mathrm{~m}^{3} \text { and } 84 \mathrm{~m}^{3} \text { (with cleaner } \\
\text { production development) }\end{array}$ \\
\hline
\end{tabular}

\subsection{Financial feasibility analysis}

In this study, the financial feasibility was determined by four categories i.e. Net Present Value, Interest Rate of Return, Return on Investment and Profitability Index. The analysis will measure whether NPV $>0$, IRR $>$ market interest rate $(12 \%)$, ROI $>0$, and Profitability Index $>1$, which therefore the scheme is considered to be financially feasible.

Table 3. Financial feasibility calculation.

\begin{tabular}{|c|c|c|c|c|c|c|c|c|c|c|c|c|}
\hline \multirow{2}{*}{$\begin{array}{c}\text { Debtor } \\
\text { Interest } \\
\text { Rate } \\
\end{array}$} & \multicolumn{3}{|c|}{ NPV (IDR million) } & \multicolumn{3}{|c|}{ IRR (\%) } & \multicolumn{3}{|c|}{ ROI (\%) } & \multicolumn{3}{|c|}{ PI } \\
\hline & $94 \mathrm{~m}^{3}$ & $84 \mathrm{~m}^{3}$ & $90 \mathrm{~m}^{3}$ & $94 \mathrm{~m}^{3}$ & $84 \mathrm{~m}^{3}$ & $90 \mathrm{~m}^{3}$ & $94 \mathrm{~m}^{3}$ & $84 \mathrm{~m}^{3}$ & $90 \mathrm{~m}^{3}$ & $94 \mathrm{~m}^{3}$ & $84 \mathrm{~m}^{3}$ & $90 \mathrm{~m}^{3}$ \\
\hline $0 \%$ & 103.65 & 193.7 & -49.38 & $\begin{array}{c}19.13 \\
\%\end{array}$ & $\begin{array}{c}30.28 \\
\%\end{array}$ & $7.50 \%$ & $\begin{array}{c}20.10 \\
\%\end{array}$ & $\begin{array}{c}390.29 \\
\%\end{array}$ & $\begin{array}{c}80.68 \\
\%\end{array}$ & 1.70 & 2.83 & 0.59 \\
\hline
\end{tabular}


Table 3. Financial feasibility calculation (continue)

\begin{tabular}{|c|c|c|c|c|c|c|c|c|c|c|c|c|}
\hline \multirow{2}{*}{$\begin{array}{c}\text { Debtor } \\
\text { Interest } \\
\text { Rate }\end{array}$} & \multicolumn{3}{|c|}{ NPV (IDR million) } & \multicolumn{3}{|c|}{ IRR (\%) } & \multicolumn{3}{|c|}{ ROI (\%) } & \multicolumn{3}{|c|}{ PI } \\
\hline & $94 \mathrm{~m}^{3}$ & $84 \mathrm{~m}^{3}$ & $90 \mathrm{~m}^{3}$ & $94 \mathrm{~m}^{3}$ & $84 \mathrm{~m}^{3}$ & $90 \mathrm{~m}^{3}$ & $94 \mathrm{~m}^{3}$ & $84 \mathrm{~m}^{3}$ & $90 \mathrm{~m}^{3}$ & $94 \mathrm{~m}^{3}$ & $84 \mathrm{~m}^{3}$ & $90 \mathrm{~m}^{3}$ \\
\hline $1 \%$ & 100.21 & 191.24 & -52.18 & $\begin{array}{c}18.83 \\
\%\end{array}$ & $29.88 \%$ & $7.29 \%$ & \begin{tabular}{|c|}
19.95 \\
$\%$
\end{tabular} & $\begin{array}{c}383.05 \\
\%\end{array}$ & \begin{tabular}{|c|}
78.01 \\
$\%$
\end{tabular} & 1.68 & 2.81 & 0.57 \\
\hline $2 \%$ & 96.77 & 188.79 & -54.97 & $\begin{array}{c}18.53 \\
\%\end{array}$ & $29.49 \%$ & $7.09 \%$ & \begin{tabular}{|c|}
19.79 \\
$\%$
\end{tabular} & \begin{tabular}{|c|}
376.01 \\
$\%$
\end{tabular} & \begin{tabular}{|c|}
75.42 \\
$\%$
\end{tabular} & 1.65 & 2.79 & 0.54 \\
\hline $3 \%$ & 93.32 & 186.33 & -57.76 & $\begin{array}{c}18.24 \\
\%\end{array}$ & $29.11 \%$ & $6.89 \%$ & \begin{tabular}{|c|}
19.64 \\
$\%$
\end{tabular} & $\begin{array}{c}369.18 \\
\%\end{array}$ & \begin{tabular}{|c|}
72.90 \\
$\%$
\end{tabular} & 1.63 & 2.76 & 0.52 \\
\hline $4 \%$ & 89.88 & 183.87 & -60.55 & $\begin{array}{c}17.96 \\
\%\end{array}$ & $28.73 \%$ & $6.69 \%$ & \begin{tabular}{|c|}
19.49 \\
$\%$
\end{tabular} & $\begin{array}{c}362.54 \\
\%\end{array}$ & \begin{tabular}{|c|}
70.45 \\
$\%$
\end{tabular} & 1.61 & 2.74 & 0.5 \\
\hline $5 \%$ & 86.44 & \begin{tabular}{|l|l}
181.41 \\
\end{tabular} & -63.34 & $\begin{array}{c}17.67 \\
\% \\
\end{array}$ & $28.36 \%$ & $6.50 \%$ & \begin{tabular}{|c|}
19.33 \\
$\%$ \\
\end{tabular} & \begin{tabular}{|c|}
356.09 \\
$\%$
\end{tabular} & \begin{tabular}{|c|}
68.08 \\
$\%$
\end{tabular} & 1.58 & 2.72 & 0.47 \\
\hline $6 \%$ & 83.00 & 178.95 & -66.13 & $\begin{array}{c}17.40 \\
\%\end{array}$ & $27.99 \%$ & $6.31 \%$ & \begin{tabular}{|c|}
19.18 \\
$\%$
\end{tabular} & $\begin{array}{c}349.81 \\
\%\end{array}$ & \begin{tabular}{|c|}
65.76 \\
$\%$
\end{tabular} & 1.56 & 2.69 & 0.45 \\
\hline $7 \%$ & 79.56 & 176.49 & -68.92 & $\begin{array}{c}17.13 \\
\%\end{array}$ & $27.63 \%$ & $6.12 \%$ & \begin{tabular}{|c|}
19.03 \\
$\%$
\end{tabular} & $\begin{array}{c}343.70 \\
\%\end{array}$ & \begin{tabular}{|c|}
63.51 \\
$\%$ \\
\end{tabular} & .54 & .67 & 0.43 \\
\hline $8 \%$ & 76.12 & 174.04 & -71.71 & $\begin{array}{c}16.86 \\
\%\end{array}$ & $27.28 \%$ & $5.94 \%$ & \begin{tabular}{|c|}
8.88 \\
$\%$
\end{tabular} & $\begin{array}{c}337.76 \\
\%\end{array}$ & \begin{tabular}{|c|}
61.32 \\
$\%$
\end{tabular} & 1.51 & 2.65 & 0.4 \\
\hline $9 \%$ & 72.68 & 171.58 & -74.50 & $\begin{array}{c}16.60 \\
\%\end{array}$ & $26.93 \%$ & $5.76 \%$ & \begin{tabular}{|c|}
18.73 \\
$\%$
\end{tabular} & $\begin{array}{c}331.97 \\
\%\end{array}$ & \begin{tabular}{|c|}
59.19 \\
$\%$
\end{tabular} & 1.49 & 2.62 & 0.38 \\
\hline $10 \%$ & 69.23 & 169.12 & -77.29 & $\begin{array}{c}16.30 \\
\% \\
\end{array}$ & $26.58 \%$ & $5.58 \%$ & \begin{tabular}{|c|}
18.58 \\
$\%$
\end{tabular} & $\begin{array}{c}326.34 \\
\%\end{array}$ & \begin{tabular}{|c|}
57.11 \\
$\%$ \\
\end{tabular} & 1.47 & 2.60 & 0.36 \\
\hline $11 \%$ & 65.79 & 166.66 & -80.08 & $\begin{array}{c}16.10 \\
\% \\
\end{array}$ & $26.25 \%$ & $5.41 \%$ & \begin{tabular}{|c|}
18.43 \\
$\%$
\end{tabular} & $\begin{array}{c}320.85 \\
\%\end{array}$ & \begin{tabular}{|c|}
55.09 \\
$\%$
\end{tabular} & 1.44 & 2.58 & 0.33 \\
\hline $12 \%$ & 62.35 & 164.2 & -82.87 & $\begin{array}{c}15.80 \\
\% \\
\end{array}$ & $25.91 \%$ & $5.24 \%$ & \begin{tabular}{|c|}
18.28 \\
$\%$
\end{tabular} & $\begin{array}{c}315.50 \\
\%\end{array}$ & \begin{tabular}{|c|}
53.12 \\
$\%$ \\
\end{tabular} & 1.42 & 2.55 & 0.31 \\
\hline $13 \%$ & 58.91 & 161.74 & -85.66 & $\begin{array}{c}15.60 \\
\% \\
\end{array}$ & $25.59 \%$ & $5.07 \%$ & \begin{tabular}{|c|}
18.13 \\
$\%$ \\
\end{tabular} & $\begin{array}{c}310.29 \\
\%\end{array}$ & \begin{tabular}{|c|}
51.20 \\
$\%$
\end{tabular} & 1.40 & 2.53 & 0.29 \\
\hline $13.5 \%$ & 57.19 & 160.51 & -87.06 & $\begin{array}{c}15.50 \\
\%\end{array}$ & $25.43 \%$ & $4.99 \%$ & $\begin{array}{c}18.05 \\
\%\end{array}$ & \begin{tabular}{|c}
307.73 \\
$\%$
\end{tabular} & $\begin{array}{c}50.26 \\
\%\end{array}$ & 1.39 & 2.52 & 0.27 \\
\hline
\end{tabular}

The financial feasibility analysis is in-line with the notion to support the provision of interest subsidy to the farmers. The higher burdens of the debtor results smaller level of the financial indicators means less feasible the program. Further, according to the result, bio digester with size $94 \mathrm{~m}^{3}$ and $84 \mathrm{~m}^{3}$ are financially feasible, whilst the $90 \mathrm{~m}^{3}$ is not feasible.

\subsection{Cost and Benefit Analysis}

The cost and benefit analysis was employed by measuring the cost, the benefit and then comparing both to find the result. The project is feasible if the ratio is above 1 .

Table 4. Cost and benefit analysis.

\begin{tabular}{|l|l|l|l|l|}
\hline No. & \multicolumn{1}{|c|}{ Indicator } & \multicolumn{1}{|c|}{$\mathbf{9 4} \mathbf{~ m}^{\mathbf{3}}$} & \multicolumn{1}{|c|}{$\mathbf{8 4} \mathbf{~ m}^{\mathbf{3}}$} & \multicolumn{1}{|c|}{$\mathbf{9 0 \mathbf { ~ m } ^ { \mathbf { 3 } }}$} \\
\hline 1 & Initial Cost (IDR) & $\begin{array}{l}148000 \\
000\end{array}$ & $\begin{array}{l}105720 \\
000\end{array}$ & $\begin{array}{l}120000 \\
000\end{array}$ \\
\hline 2 & Loan Tenure (Year) & $5 \mathrm{yr}$ & $5 \mathrm{yr}$ & $5 \mathrm{yr}$ \\
\hline 3 & Lended Interest Rate & $13.5 \%$ & $13.5 \%$ & $13.5 \%$ \\
\hline 4 & Interest Rate Borne by Beneficiaries (Scenarios) \\
\hline A. & $\begin{array}{l}\text { Scenario 1: Interest Rate Borne by } \\
\text { Beneficiaries }\end{array}$ & $0.0 \%$ & $0.0 \%$ & $0.0 \%$ \\
\hline \multicolumn{5}{|l|}{ continue on next page } \\
\hline
\end{tabular}




\begin{tabular}{|c|c|c|c|c|}
\hline \multicolumn{5}{|c|}{ Table 4. Cost and benefit analysis (continue) } \\
\hline No. & Indicator & $94 \mathrm{~m}^{3}$ & $84 \mathrm{~m}^{3}$ & $90 \mathrm{~m}^{3}$ \\
\hline & Interest Subsidy & $13.5 \%$ & $13.5 \%$ & $13.5 \%$ \\
\hline & Cost (C) (IDR) & $\begin{array}{l}302109 \\
086\end{array}$ & $\begin{array}{l}215127 \\
576\end{array}$ & $\begin{array}{l}244185 \\
671\end{array}$ \\
\hline & Benefit (B) (IDR) & $\begin{array}{l}753439 \\
700\end{array}$ & $\begin{array}{l}547826 \\
431\end{array}$ & $\begin{array}{l}462564 \\
344\end{array}$ \\
\hline & Net Benefit (IDR) & $\begin{array}{l}451330 \\
614\end{array}$ & $\begin{array}{l}332698 \\
855\end{array}$ & $\begin{array}{l}218378 \\
672\end{array}$ \\
\hline & B per C Ratio (BCR) & 2.49 & 2.55 & 1.89 \\
\hline & Feasibility (If BCR > 1) & Feasible & Feasible & Feasible \\
\hline & $\mathrm{CO} 2$ Emission Reduction ( $\mathrm{t}$ ) & 1557 & 321 & 862 \\
\hline B. & $\begin{array}{l}\text { Scenario 2: Interest Rate Borne by } \\
\text { Beneficiaries }\end{array}$ & $1.0 \%$ & $1.0 \%$ & $1.0 \%$ \\
\hline & Interest Subsidy & $12.5 \%$ & $12.5 \%$ & $12.5 \%$ \\
\hline & Cost (C) (IDR) & $\begin{array}{l}302109 \\
086\end{array}$ & $\begin{array}{l}215127 \\
576\end{array}$ & $\begin{array}{l}244185 \\
671\end{array}$ \\
\hline & Benefit (B) (IDR) & $\begin{array}{l}753439 \\
700\end{array}$ & $\begin{array}{l}547826 \\
431\end{array}$ & $\begin{array}{l}462564 \\
344\end{array}$ \\
\hline & Net Benefit (IDR) & $\begin{array}{l}451330 \\
614 \\
\end{array}$ & $\begin{array}{l}332698 \\
855\end{array}$ & $\begin{array}{l}218378 \\
672\end{array}$ \\
\hline & B per C Ratio (BCR) & 2.49 & 2.55 & 1.89 \\
\hline & Feasibility (If BCR > 1) & Feasible & Feasible & Feasible \\
\hline & $\mathrm{CO}_{2}$ Emission Reduction $(\mathrm{t})$ & 1557 & 321 & 862 \\
\hline
\end{tabular}

The above table shows that the CBA results all sizes are feasible. The ratios of BCR are more than 1 for all of the investments. The highest level comes from size $84 \mathrm{~m}^{3}$ at 2.55 , followed by $94 \mathrm{~m}^{3}$ with 2.49 and 1.89 for $90 \mathrm{~m}^{3}$.

Even though the financial feasibility analysis and cost and benefit analysis give a positive result to the support of the WtE program, there are several key success factors that may give impact to the success of the program i.e.:

- Fossil energy and electricity prices are high and not subsidized,

- Conducted to substitute fossil energy types,

- Sustainable availability of waste,

- Limited land for waste disposal,

- High tipping fee for disposal of garbage/waste,

- Policies for better WTE support,

- Public support.

\section{Conclusion and recommendation}

The result of the study shows that financially, not all development of WtE for Tofu Industry types are feasible to develop. It is only for $84 \mathrm{~m}^{3}$, and $94 \mathrm{~m}^{3}$ investments are financially feasible. While on the other hand, economically, all kinds development of WTE Tofu industry as a focus in this study deserves to be developed.

To make it more financially feasible, interest subsidies are needed to finance the development of WTE Tofu Industry. When using existing credit scheme, KKP-E (with revision in the regulation), $\mathrm{WtE}$ for biogas from tofu industry are potential, where the primary concern is the large investment required can be up to IDR 100000000 for individual and IDR 500000000 for the group (communal). 
The authors gratefully acknowledge the support from Ministry of Energy and Mineral Resources and Ministry of Finance. This study was also supported by United Kingdom Climate Change Unit (UKCCU).

\section{References}

1. Ministry of Finance. Peraturan menteri keuangan nomor 79/PMK.05/2007 tentang kredit ketahanan pangan dan energi [minister of finance decree number 79/PMK.05/2007 on credit for food and energy security] [Online] from http://www.sjdih.depkeu.go.id/fulltext/2007/79 pmk.05 2007per.htm (2007). [Accessed on 20 May 2016]. [in Bahasa Indonesia]

2. Ministry of Finance. [Minister of Finance Decree Number 48/PMK.05/2009 on Credit for Food and Energy Security (2009) [Kredit Ketahanan Pangan dan Energi]

3. Ministry of Finance. Peraturan menteri keuangan nomor 198/PMK.05/2010 tentang perubahan kedua atas peraturan menteri keuangan nomor 79/PMK.05/2007 tentang kredit ketahanan pangan dan energi [minister of finance decree number 198/PMK.05/2009 on second amendment for minister of finance decree number 79/PMK.05/2007 credit on food and energy security] [Online] from https://peraturan.bkpm.go.id/jdih/userfiles/batang/Permenkeu_198_PMK05_2010.pdf. (2010). [Accessed on 20 May 2016]. [in Bahasa Indonesia]

4. C.C. Bode, T.J. Sheer. J. energy South. Afr. 21, 2:2-11 (2010). http://www.scielo.org.za/scielo.php?pid=S1021447X2010000200001\&script $=$ sci abstract

5. I.J. Altman, T.G. Johnson, P.C. Badger, S.J. Orr. Journal of EUEC 1 (2007). https://www.researchgate.net/publication/258398752_Financial_Feasibility_and_Regio nal_Economic_Impacts Three_Case_Studies in_US Biopower

6. I. Ahmad, I. Hermadi, Y. Arkeman. TELKOMNIKA Indonesian Journal of Electrical Engineering 13, 3:546-554 (2015). https://pdfs.semanticscholar.org/253f/4accc17a17cb1d0757a00a4fdd7ab06dfe7e.pdf.

7. A.S. Abdelmajeed, and M. H. Aboul-Nasr. Journal of Finance, Accounting and Management, 4 2:87-96 (2013). http://www.gsmiijgb.com/Documents/JFAM $\% 20$ V4\%20N2\%20P06\%20Suzan $\% 20$ Abdelmajeed $\% 20$ Financial $\% 20$ Feasibility $\% 20$ Study $\% 20$ of $\% 20$ Bananas $\% 20$ Tissue.pdf.

8. B. Z. Diomedi, L. Gunn, B. G. Corti, A. Shiell, and J. L. Veerman. Preventive Medicine, 106, 224-230 (2018). https://www.sciencedirect.com/science/article/pii/S0091743517304504.

9. G. Battistoni, M. Genco, M. Marsilio, C. Pancotti, S. Rossi, and S. Vignetti. Technological Forecasting and Social Change, 112, 79-91 (2016). https://www.sciencedirect.com/science/article/pii/S0040162516300233.

10. B. P. Horn, C. Crandall, A. Forcehimes, M. T. French, and M. Bogenschutz. Journal of Substance Abuse Treatment, 79, 6-11 (2017). https://www.sciencedirect.com/science/article/pii/S0740547216302963.

11. S. Greenhalgh, O. Samarasinghe, F. Curran-Cournane, W. Wright, and P. Brown. Ecosystem Services, 27, A: 1-14 (2017). https://www.sciencedirect.com/science/article/pii/S2212041616304715.

12. E. Ustaoglu, B. Williams, and E. Murphy. Case Studies on Transport Policy, 4, 2: 104121 (2016). https://www.sciencedirect.com/science/article/pii/S2213624X16300037.

13. A. Kumar and K. Nair. International Journal of Energy, Information and Communications, 4, 1:51-62 (2013). http://repository.usp.ac.fj/5795/

14. Ministry of Finance. Peraturan menteri keuangan nomor 117/PMK 06/2006 tentang kredit pengembangan energi nabati dan revitalisasi perkebunan [minister of finance 
decree number 117/PMK.06/2006 on credit for bio energy development and plantation revitalization] [Online] from http://www.sjdih.depkeu.go.id/fulltext/2006/117 PMK.06 2006Per.htm (2006). [Accessed on 5 April 2016]. [in Bahasa Indonesia]

15. Ministry of Agriculture. Peraturan menteri pertanian nomor: 33/Permentan/OT.140/7/2006 tentang pengembangan perkebunan melalui program revitalisasi perkebunan [ministry of agriculture decree number 33/Permentan/OT.140/7/2006 on estate development through plantation revitalization program] [Online] from http://www.iopri.org/wpcontent/uploads/2016/10/PERMENTAN-33-2006-REVITALISASIPERKEBUNAN.pdf (2006). [Accessed on 5 April 2016]. [in Bahasa Indonesia]

16. Ministry of Finance. Peraturan menteri keuangan nomor 135/PMK.05/2008 tentang fasilitas penjaminan kredit usaha rakyat [minister of finance decree number No.135/PMK.05/2008 on credit for businesses program] [Online] from http://www.jdih.kemenkeu.go.id/fullText/2008/135 PMK.05 2008Per.htm (2008). [Accessed on 5 April 2016 ]. [in Bahasa Indonesia]

17. Ministry of Finance. Peraturan menteri keuangan nomor 131/PMK.05/2009 tentang kredit usaha pembibitan sapi [minister of finance decree number No.131/PMK.05/2009 on credit for cattle breeding] [Online] from http://www.jdih.kemenkeu.go.id/fullText/2009/131 PMK.05 2009Per.htm (2009).

[Accessed on 5 April 2016]. [in Bahasa Indonesia]

18. Ministry of Finance. Peraturan menteri keuangan Republik Indonesia nomor 241/PMK.05/2011 tentang perubahan atas peraturan meteri keuangan nomor 131/PMK.05/2009 tentang kredit usahan pembibitan sapi [minister of finance decree number No.241/PMK.05/2011 on amendment minister of finance decree number No.131/PMK.05/2009 on credit for cattle breeding] [Online] from http://ngada.org/bn906-2011.htm (2011). [Accessed on 5 April 2016]. [in Bahasa Indonesia]

19. Government of Indonesia. Peraturan presiden Republik Indonesia nomor 29 tahun 2009 tentang pemberian jaminan dan subsidi bunga oleh pemerintah pusat dalam rangka percepatan penyediaan air minum [presidential regulation number 29/2009 on the provision of guarantees and interest subsidies by the central government] [Online] from http://storage.jakstik.ac.id/ProdukHukum/Sekneg/Perpres\%2029\%20Tahun\%202009.pdf. (2009). [Accessed on 5 April 2016]. [In Bahasa Indonesia] 